\title{
EDITORIAL
}

\section{Idiopathic pulmonary fibrosis: current challenges and future perspectives}

\author{
Luca Richeldi
}

I diopathic pulmonary fibrosis (IPF) is the most prevalent of the idiopathic interstitial pneumonias and its incidence seems to be increasing [1-4]. IPF is generally considered to be unresponsive to "standard" therapies and carries a poor prognosis with most patients dying within at least 5 years following diagnosis [5-7]. An accurate diagnosis of IPF is essential for the optimal management of patients with IPF. The original IPF management guidelines, published in 2000 [8], have been superseded recently by the evidence-based international recommendations jointly sponsored by the European Respiratory Society (ERS), the American Thoracic Association (ATS), the Japanese Respiratory Society (JRS) and the Latin American Thoracic Association (ALAT) [9]. Nonetheless, despite this and other major accomplishments over the last decade, the diagnosis and the management of IPF remain a major medical challenge. Diagnostic uncertainties remain due, at least in part, to variability in the natural history of the disease and co-existing complicating comorbidities, interpretation and widespread application of the guideline recommendations, and analysis of histological and radiographic assays, as well as a paucity of accurate indicators of disease progression and response to treatment.

Since a cure for IPF is not currently available, the treatment goal is to stabilise or reduce the rate of disease progression. There have been significant and encouraging increases in the number, size and quality of randomised clinical trials in IPF over the past decade (fig. 1) [10-23], and novel anti-fibrotic agents with the potential to realise this treatment goal are now starting to emerge. For example, although the 2011 guidelines committee did not recommend any single pharmacological agent, pirfenidone has been approved for clinical use in Europe.

The identification of more accurate and objective predictors of clinical status, prognosis and survival estimates in IPF is also critical for clinical management and individual treatment decision making [24]. There is also an ongoing debate on the choice of primary end-point for use in clinical trials of treatments for IPF. Improvements in molecular techniques have expanded our understanding of IPF and have led to the

Centre for Rare Lung Disease, Policlinico University Hospital, Modena, Italy.

CORRESPONDENCE: L. Richeldi, Centre for Rare Lung Disease, Policlinico University Hospital, Via del Pozzo 71, Modena 41124, Italy. E-mail: luca.richeldi@unimore.it

PROVENANCE: Publication of this peer-reviewed article was supported by InterMune Inc., USA (principal sponsor, European Respiratory Review issue 128). identification of new molecular pathways, thus shaping the potential for a more targeted therapeutic approach [25, 26]. While genetic studies have provided some insights into the pathogenesis of IPF, more functional studies that confirm their significance and studies investigating other mutations, associations and gene-environment relationships are required [27-30].

This issue of the European Respiratory Review includes a series of state-of-the-art articles based on presentations by prominent IPF experts at the recent 2012 ERS Annual Congress in Vienna, Austria, and the 17th International Colloquium on Lung and Airways Fibrosis (ICLAF) held in Modena, Italy. The articles review the substantial progress that has been made in the pathogenesis, diagnosis, management and treatment of IPF, but also anticipate the future advances in the understanding and clinical management of IPF. In the first article, WeLLS [31] provides a critical review and the latest insights into managing diagnostic procedures in IPF and identifies limitations that should be addressed in future consensus statements. BEHR [32] then provides an updated evaluation of clinical study and evidence-based data of novel treatment strategies in IPF, including the latest results from the pirfenidone CAPACITY (Clinical Studies Assessing Pirfenidone in Idiopathic Pulmonary Fibrosis: Research of Efficacy and Safety Outcomes) clinical trials and the subsequent open-label extension study, RECAP (Open-label roll-over study from CAPACITY). MAHER [33] goes on to identify the most recent potential biomarkers and disease fingerprint of IPF and describes the ongoing PROFILEing (Prospective Observation of Fibrosis in the Lung Clinical Endpoints) Study, an innovative UK-based multicentre prospective cohort study that aims to characterise composite biological and clinical trial end-points. Finally, COTTIN [34] describes the impact of a new syndrome, in which pulmonary fibrosis co-exists with pulmonary emphysema. Combined pulmonary fibrosis and emphysema (CPFE) is a strong determinant of secondary pulmonary hypertension and further studies are needed to ascertain the aetiology, morbidity, mortality and management of CPFE, with or without pulmonary hypertension, and to evaluate novel therapeutic options.

The expert contributions in this series of articles indicate that there is room for cautious optimism in this challenging era of respiratory medicine, and that we may be entering an era in which prevention of IPF progression may become a reasonable therapeutic goal. Recently updated guidelines have provided important recommendations for the diagnosis and pharmacological and 


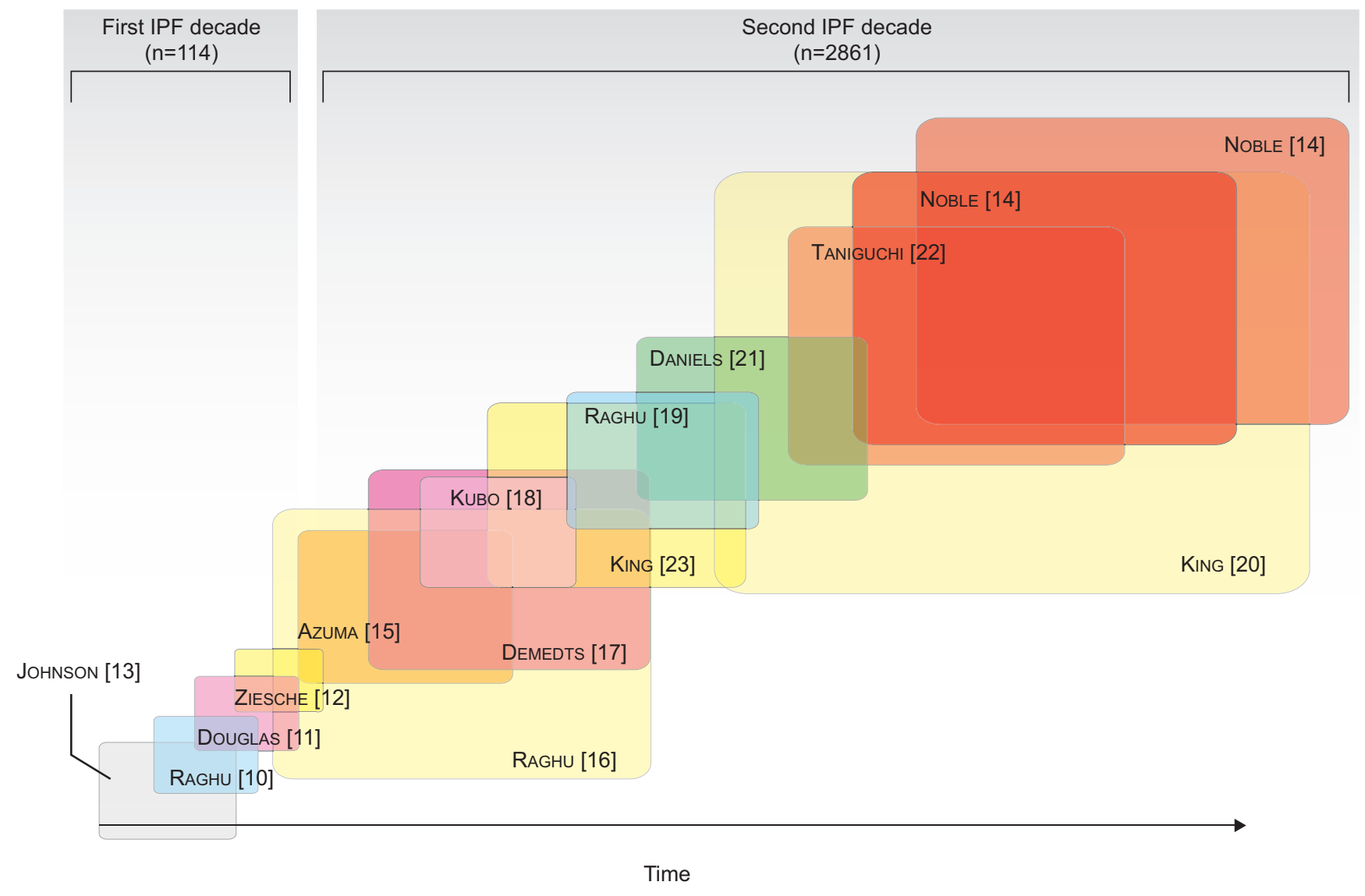

FIGURE 1. The number of patients enrolled in clinical studies of idiopathic pulmonary fibrosis (IPF) has increased substantially in the past decade compared to the previous decade [10-23].

non-pharmacological management of patients with IPF. The ability of physicians to achieve a confident diagnosis has greatly improved, and the proliferation of clinical trials has started to build an evidence base upon which rational treatment decisions can be built.

\section{STATEMENT OF INTEREST}

Conflict of interest information can be found alongside the online version of this article at err.ersjournals.com

\section{ACKNOWLEDGMENTS}

I received medical writing support from IntraMed International (Milan, Italy), which was funded by InterMune Inc. (Brisbane, CA, USA).

\section{REFERENCES}

1 Eurostat News Release. European demography EU27 population 501 million at 1 January 2010. More than 5 million children born in the EU27 in 2009. 110/2010. 27 July 2010. http://epp.eurostat.ec. europa.eu/cache/ITY_PUBLIC/3-27072010-AP/EN/3-27072010-APEN.PDF Date last updated: July 27, 2010. Date last accessed: April 14, 2013.

2 Coultas DB, Zumwalt RE, Black WC, et al. The epidemiology of interstitial lung diseases. Am J Respir Crit Care Med 1994; 150: 967-972.

3 Navaratnam V, Fleming KM, West J, et al. The rising incidence of idiopathic pulmonary fibrosis in the UK. Thorax 2011; 66: 462-467.
4 Gribbin J, Hubbard RB, Le Jeune I, et al. Incidence and mortality of idiopathic pulmonary fibrosis and sarcoidosis in the UK. Thorax 2006; 61: 980-985.

5 Carrington CB, Gaensler EA, Coutu RE, et al. Natural history and treated course of usual and desquamative interstitial pneumonia. N Engl J Med 1978; 298: 801-809.

6 Tukiainen P, Taskinen E, Holsti P, et al. Prognosis of cryptogenic fibrosing alveolitis. Thorax 1983; 38: 349-355.

7 Gross TJ, Hunninghake GW. Idiopathic pulmonary fibrosis. N Engl J Med 2001; 345: 517-525.

8 American Thoracic Society. Idiopathic pulmonary fibrosis: diagnosis and treatment. International consensus statement. American Thoracic Society (ATS), and the European Respiratory Society (ERS). Am I Respir Crit Care Med 2000; 161: 646-664.

9 Raghu G, Collard HR, Egan JJ, et al. An Official ATS/ERS/JRS/ ALAT statement: idiopathic pulmonary fibrosis: evidence-based guidelines for diagnosis and management. Am J Respir Crit Care Med 2011; 183: 788-824.

10 Raghu G, Depaso WJ, Cain K, et al. Azathioprine combined with prednisone in the treatment of idiopathic pulmonary fibrosis: a prospective double-blind, randomized, placebo-controlled clinical trial. Am Rev Respir Dis 1991; 144: 291-296.

11 Douglas WW, Ryu JH, Swensen SJ, et al. Colchicine versus prednisone in the treatment of idiopathic pulmonary fibrosis. A randomized prospective study. Am J Respir Crit Care Med 1998; 158: 220-225.

12 Ziesche R, Hofbauer E, Wittmann K, et al. A preliminary study of long-term treatment with interferon $\gamma-1 \mathrm{~b}$ and low-dose prednisolone in patients with idiopathic pulmonary fibrosis. $N$ Engl J Med 1999; 341: 1264-1269. 
13 Johnson MA, Kwan S, Snell NJ, et al. Randomised controlled trial comparing prednisolone alone with cyclophosphamide and low dose prednisolone in combination in cryptogenic fibrosing alveolitis. Thorax 1989; 44: 280-288.

14 Noble PW, Albera C, Bradford WZ, et al. Pirfenidone in patients with idiopathic pulmonary fibrosis (CAPACITY: two randomised trials). Lancet 2011; 377: 1760-1769.

15 Azuma A, Nukiwa T, Tsuboi E, et al. Double-blind, placebocontrolled trial of pirfenidone in patients with idiopathic pulmonary fibrosis. Am J Respir Crit Care Med 2005; 171: 1040-1047.

16 Raghu G, Brown KK, Bradford WZ, et al. A placebo-controlled trial of interferon $\gamma-1 \mathrm{~b}$ in patients with idiopathic pulmonary fibrosis. N Engl J Med 2004; 350: 125-133.

17 Demedts M, Behr J, Buhl R, et al. High-dose acetylcysteine in idiopathic pulmonary fibrosis. N Engl J Med 2005; 353: 2229-2242.

18 Kubo H, Nakayama K, Yanai M, et al. Anticoagulant therapy for idiopathic pulmonary fibrosis. Chest 2005; 128: 1475-1482.

19 Raghu G, Brown KK, Costabel U, et al. Treatment of idiopathic pulmonary fibrosis with etanercept: an exploratory, placebocontrolled trial. Am J Respir Crit Care Med 2008; 178: 948-955.

20 King TE Jr, Albera C, Bradford WZ, et al. Effect of interferon $\gamma-1 \mathrm{~b}$ on survival in patients with idiopathic pulmonary fibrosis (INSPIRE): a multicentre, randomised, placebo-controlled trial Lancet 2009; 374: 222-228.

21 Daniels CE, Lasky JA, Limper AH, et al. Imatinib treatment for idiopathic pulmonary fibrosis: randomized placebo-controlled trial results. Am J Respir Crit Care Med 2010; 181: 604-610.

22 Taniguchi H, Ebina M, Kondoh Y, et al. Pirfenidone in idiopathic pulmonary fibrosis. Eur Respir J 2010; 35: 821-829.
23 King TE Jr, Behr J, Brown KK, et al. BUILD-1: a randomized placebo-controlled trial of bosentan in idiopathic pulmonary fibrosis. Am J Respir Crit Care Med 2008; 177: 75-81.

24 Thomeer M, Grutters JC, Wuyts WA, et al. Clinical use of biomarkers of survival in pulmonary fibrosis. Respir Res 2010; 11: 89.

25 Zhang Y, Kaminski N. Biomarkers in idiopathic pulmonary fibrosis. Curr Opin Pulm Med 2012; 18: 441-446.

26 Mahendran S, Sethi T. Treatments in idiopathic pulmonary fibrosis: time for a more targeted approach? QJM 2012; 105: 929-934.

27 Grutters JC, du Bois RM. Genetics of fibrosing lung diseases. Eur Respir J 2005; 25: 915-927.

28 Verleden GM, du Bois RM, Bouros D, et al. Genetic predisposition and pathogenetic mechanisms of interstitial lung diseases of unknown origin. Eur Respir J 2001; 18: Suppl. 32, 17s-29s.

29 van Moorsel CH, van Oosterhout MF, Barlo NP, et al. Surfactant protein $\mathrm{C}$ mutations are the basis of a significant portion of adult familial pulmonary fibrosis in a Dutch cohort. Am J Respir Crit Care Med 2010; 182: 1419-1425.

30 Seibold MA, Wise AL, Speer MC, et al. A common MUC5B promoter polymorphism and pulmonary fibrosis. $N$ Engl J Med 2011; 364: 1503-1512.

31 Wells AU. Managing diagnostic procedures in idiopathic pulmonary fibrosis. Eur Respir Rev 2013; 22: 158-162.

32 Behr J. Evidence-based treatment strategies in idiopathic pulmonary fibrosis. Eur Respir Rev 2013; 22: 163-168.

33 Maher TM. PROFILEing idiopathic pulmonary fibrosis: rethinking biomarker discovery. Eur Respir Rev 2013; 22: 148-152.

34 Cottin V. The impact of emphysema in pulmonary fibrosis. Eur Respir Rev 2013; 22: 153-157. 